\section{A universal Hamlet?}

SIR - J. R. Smythies' suggestion that Wittgenstein was paranoid (Nature 350,9; 1991) is intriguing and calls for comment.

It is generally known that before the worldwide acceptance of the DSM III criteria, the diagnosis of schizophrenia was used with quite different meanings by North American, European and Soviet psychiatrists, and that there are still no biological tests for schizophrenia. The situation today is well illustrated by the aphorism of Pascal: "When we do not know the truth of a thing it is of advantage that there should exist a common error."

In the wittgensteinian sense, the concept of schizophrenia could even be seen as a spurious attempt to grasp and classify human madness in scientific terms, and Smythies' letter is a warning of what may happen when people are privileged by virtue of their psychiatric training and identification to decide what is sound and scientific.

The following note by Wittgenstein demonstrates that he was deeply aware of the hazards inherent in his way of thinking, doubting and perceiving the world:

Ich sitze mit einem Philosophen im Garten; er sagt zu wiederholten Malen "Ich weiss, dass das ein Baum ist" wobei er auf einem Baum in unserer Nähe zeigt. Ein Dritter kommt daher und hört das, und ich sage ihm: "Dieser Mensch ist nicht verrückt: wir philosophieren nur".

[I am sitting with a philosopher in the garden; he says again and again "I know that that's a tree", pointing to a tree that is near us. Someone else arrives and hears this, and I tell him: "This fellow isn't insane. We are only doing philosophy."]

Thus the claim that the writings of Wittgenstein should be read as nonsense poetry lacking a scientific dimension is not surprising.

I have referred to Wittgenstein's studies on certainty in support of my theory that Shakespeare approached the mystery of madness in an experimental way by studying the genesis and consequences of a 'false' experience of truth (Othello, Macbeth), and what happens when our natural inclination to act according to the experience of truth is lost (Hamlet). I now propose that Wittgenstein, instead of being labelled as a schizophrenic, should rather be regarded as a universal Hamlet figure of our time.

\section{Haaga Neurological}

Rehabilitation Centre,

PL 4, 00321 Helsinki,

Finland

SIR - J. R. Smythies' letter ${ }^{1}$ on Wittgenstein raises a number of questions: (1) If schizophrenia, a serious mental illness, is compatible with the achievement and international stature of Ludwig Wittenstein, should not the concept of mental 'illness' be redefined? (2) Should scientific, philosophical and literary texts, as well as people, be subject to medical certification? Should we question the validity of the kinetic theory of matter, because one of its originators, Ludwig Boltzmann, took his own life? (3) Is mental health conformity to a norm, or to an ideal? If the former is correct, is it abnormal to be extremely virtuous? (4) What is Smythies' professional opinion of such writers as Jonathan Swift, Edgar Allan Poe and Blaise Pascal (not to mention such extreme cases as those of Charles Baudelaire and Jean Jacques Rousseau)?

Incidentally, the metaphorical, or the highly suggestive, use of language, described as "schizophrenese" by Smythies, has met with a happier treatment by Pascal: "Nous connaissons la vérité non seulement par la raison, mais encore par le coeur" - "We recognize truth not only through reason but also through the heart". Again, such an extreme rationalist philosopher as Spinoza acknowledges intuition as the highest form of knowledge ("cognitio Dei intuitiva" - " the intuitive knowledge of God").

EMmANUEL T. RAKITZIS Department of Biological Chemistry, University of Athens Medical School, Athens,

11527 Greece

1. Smythies, J. R. Nature 350, 9 (1990)

2. Pascal, B. Pensées, p. 73 (Nouveaux Classiques Larousse, Paris, 1965).

3. Spinoza, B. Ethica, V. Prop. XXV (van Vloten \& Land, The Hague, 1914)

\section{Origin of AIDS}

SIR - A. Karpas's letter on the "Origin and spread of AIDS" (Nature 348, 578; 1990) is surely premature in its conclusions. A combination of tribal customs involving African monkeys carrying HIV-like agents as the probable origin of AIDS in man is essentially speculative. However, the use of tissues from such animals for live human vaccine production is a fact and should be considered as a possible source of the virus. Such vaccines were also a post-Second-World-War development as was the introduction of syringes to Africa. The reference to "more than a dozen such cases" of herpesvirus simiae (B virus) infection in man, with no mention of millions of cases of SV40 transmission to man via poliovirus vaccine ${ }^{1}$ prepared in monkey tissues, is misleading.

Tribal customs in Africa are age-old, yet this disease is obviously new even to this continent. That there are now many cases of the disease in Africa is not surprising in view of the poor health conditions in most developing societies, not only in Africa. There is also a marked increase in infection by the AIDS virus in Thailand and Brazil. The evidence pointing to Africa in the origin of AIDS is tenuous at best. "Continuous mutation" is unlikely to explain the wide diver- gence between HIV-1 and HIV-2, their simultaneous appearance in man as disease agents and the continued existence in chimpanzees and other primates of closely related viruses. Even recombinants of simian viruses and endogenous human retroviruses cannot be ruled out. To single out Africa and its people and customs as essentially pivotal in this tragic pandemic is decidedly biased, and in view of the possible social and related repercussions one would urge extreme caution before embarking on such generalizations.

G. LECATSAS

Department of Microbiology,

Medical University of Southern Africa, Medunsa 0204,

South Africa

1. Shah, K. \& Nathanson, N. Am. J. Epidemiol. 103, 1-12 (1976).

\section{Misuse of words}

SIR - Although scientists use many words of Greek and Latin origin, they are often not familiar with the grammar of these ancient languages. Many words are also imitated and repeated without thinking about their real meaning. An example is the term 'recombinant'.

The Latin ending - ans, which became -ant in French and English, characterizes the present participle (active voice) and means -ing in English. Thus 'recombinant' means 'recombining'.

The use of this word is correct, for example, in 'recombinant technology'. But it is applied wrongly when speaking about the product of a recombination, for example a gene, after it has been recombined. Then it is not a 'recombinant gene' (recombining gene) but a 'recombined gene' (past participle, passive voice).

In Latin it would be 'recombinatus'. Thus, if 'recombined' does not look learned enough, I would propose 'recombinated': 'recombinated gene' instead of 'recombinant gene' does not sound bad and would be logically and linguistically correct. What is now 'a recombinant' should properly be called 'a recombination product'. (Maybe someone can invent a better word.)

There is also an old word similarly used wrongly: the noun 'mutant'. It should properly be 'a mutatus', which admittedly is an ugly word. Is there a better one that is grammatically correct?

Unfortunately, the thoughtless mechanical misuse of the term 'recombinant' (and also 'mutant') is already so deeply ingrained that it will be almost impossible to eliminate it even partially from scientific jargon and papers. But by becoming aware of this attack on common sense and grammar, at least some readers with a linguistic feeling may in future try to avoid this frequent error.

Mariahilfer Str. 133

FrIEDRICH KatSCHER

A-1150 Vienna,

Austria 